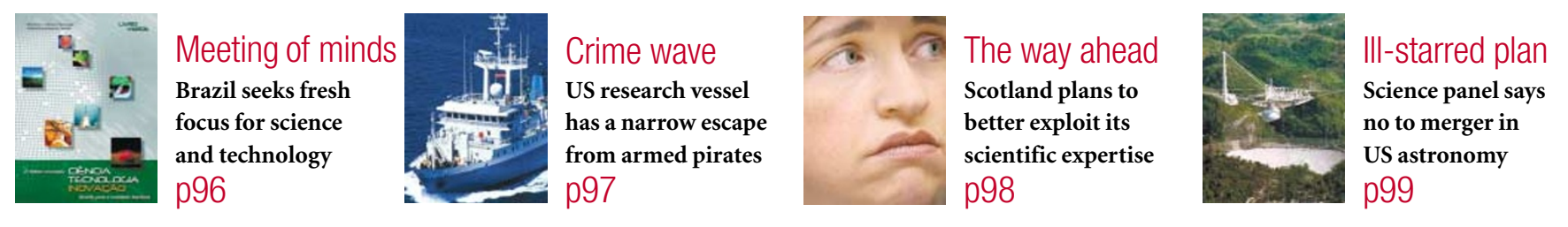

\title{
French researchers take a stand against cancer gene patent
}

Declan Butler and Sally Goodman, Paris

The Curie Institute in Paris is to challenge a European patent held by the US biotechnology company Myriad Genetics. The patent covers the BRCA1 gene, used in tests to assess a patient's predisposition to hereditary breast and ovarian cancers.

The French government is officially supporting the institute's action and intends to introduce legislation that would extend compulsory licensing to cover genetic tests.

Utah-based Myriad Genetics, which won a US monopoly on the BRCA1 gene in 1999, obtained a European patent on it in January. As a result, Europeans will be obliged to pay $\$ 2,400$ for Myriad's screening test - alternative French tests cost less than a third of this.

Worldwide, Myriad has aggressively exercised its exclusive rights to carry out diagnostic testing on BRCA1 and a related gene, $B R C A 2$. It requires that all samples for testing be sent to the company's labs in Salt Lake City.

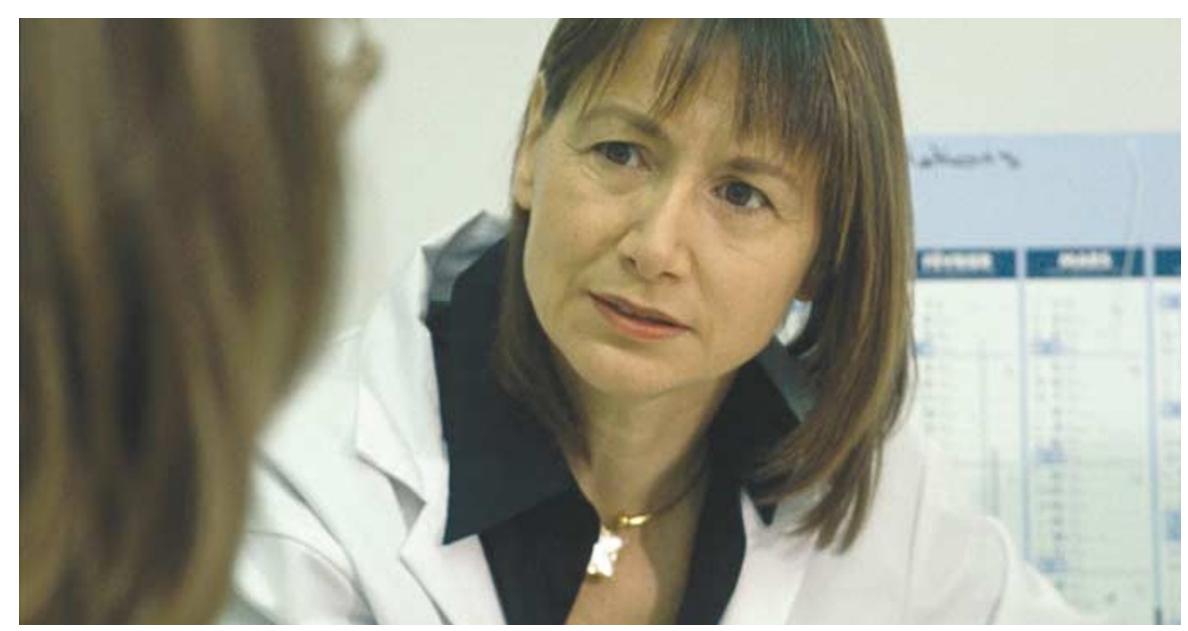

Health worries: Dominique Stoppa-Lyonnet says Myriad's test did not identify some expected mutations.

Estimates vary as to the proportion of breast cancer cases that are hereditary, but the US National Cancer Institute suggests

\section{Venture capital concerns academics}

\section{Rex Dalton, San Diego}

The University of California, San Francisco, (UCSF) has set up a scheme to fund projects aimed at generating commercial products such as drugs or equipment.

Established by Burrill, a San Francisco venture-capital firm, the scheme will provide grants of up to $\$ 500,000$ for highrisk research projects that might be unlikely to attract grants from public agencies.

If the projects are successful, Burrill would help to set up a company to exploit them, which it could own jointly with the UCSF, the faculty members involved, and the California Public Employees' Retirement System pension fund, which is making an initial investment of \$10 million.

But the arrangement was agreed by UCSF administrators without formal consent from the university faculty, some of whom are concerned about its implications for academic freedom.

The deal raises "huge potential conflict- of-interest issues", says Stanton Glantz, a cardiovascular researcher and chair of the UCSF academic senate planning committee. "This could have major impacts on the whole mission of the university," he says.

"Unfortunately, the administration felt pressured to sign the agreement before adequate vetting by the faculty," says Daniel Bickle, an endocrinologist and chair of the academic senate.

Zach Hall, the UCSF's vice chancellor for research, says money from the deal will go back into research. "Part of our mission as a state public institution is to make sure discoveries in labs are converted to products for public good," he says.

The UCSF is building a biomedical research campus, Mission Bay, at which academic and privately funded researchers are expected to work in close collaboration. The university hopes that deals such as the one with Burrill will keep it in the forefront of partnerships with the private sector. that $B R C A 1$ is responsible for about half of those cases that are genetically inherited.

Myriad's patent, EP 699754, covers all methods for diagnosing the risk of breast cancer based on comparing a sample sequence with the sequence it describes for BRCA1. At a press conference in Paris on 6 September, the Curie Institute said that it will challenge the patent on grounds of lack of novelty and inadequate description.

The institute argues that the patent draws on 'prior art' generated by public genome centres, and also that the sequence used in the initial patent application contained errors, limiting its usefulness. Jacques Warcoin, the Curie Institute's patent adviser, says that other European countries, including Germany, may join the challenge.

In addition, Dominique Stoppa-Lyonnet, a physician responsible for genetic testing of breast cancer at the Curie Institute, claims that the automated sequencing method used by the Myriad test to identify deletions and mutations detects only $10-20 \%$ of the expected mutations.

Stoppa-Lyonnet was co-author of a paper published in June (J. Med. Genet. 38, 388-391; 2001) describing a deletion in the gene accounting for the predisposition of one US family with a history of breast and ovarian cancer. The Myriad test failed to detect any $B R C A 1$ predisposition in the family, the 
authors said. They detected the new deletion - which, with 12,000 base pairs, accounts for about $15 \%$ of the gene - using a technique patented by the Pasteur Institute called combed DNA colour bar coding.

William Hockett, a spokesman for Myriad, says that the company is developing a method to detect such large deletions and that a commercial test will be available by the end of the year.

Opposition to a patent must be filed within nine months of the date the patent was granted, and Warcoin says they will wait until the 9 October deadline before filing to ensure their case is as strong as possible. Hockett says Myriad is unaware of the planned opposition, and would not comment until it had been filed.

The Curie Institute argues in particular that the requirement for samples to be sent to Myriad for testing will deny French scientists data and expertise, and will hamper development of new tests.

The opposition will also challenge the patent's breadth. As it covers all diagnostics based on the gene sequence, it allows Myriad to prevent the marketing of tests developed by the Curie Institute, and others, that use different techniques from Myriad's test.

Roger-Gérard Schwartzenberg, the French research minister, said last week that the government would introduce a bill to extend the laws that govern compulsory licensing to cover diagnostics, and consider exercising this power if Myriad refuses to license its tests to be carried out in France.

\section{Helmholtz Society prepares itself for strategic reforms}

\section{Quirin Schiermeier, Munich}

The Helmholtz Society, Germany's largest government-funded research organization, is expected to agree to sweeping reforms at its annual meeting in Berlin this week.

The reforms will introduce greater centralized control for the society's 16 research centres. The government proposed the changes earlier this year in an effort to increase the centres' relevance to industry and society, and to foster more collaboration and competition between the various sites.

The reform package will give the society's president and senate significantly more power to determine research goals and allocate funds, based on the result of scientific evaluations every five years.

But many Helmholtz researchers worry that this centralizing drive could undermine basic research and curtail their scientific independence.

Under the reforms, most of the organization's DM2.6-billion (\$US1.2-billion) annual budget will be earmarked to six strategic programmes. Researchers say that this will make it hard for them to get external grants from funding agencies, such as the European Commission, which expect host institutions to cover infrastructure and overhead costs.

In response to protests earlier this year,

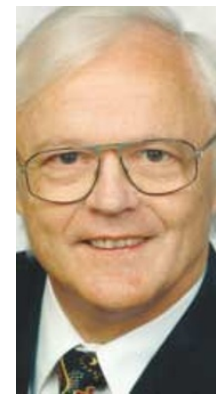

research minister Edelgard Bulmahn agreed to include "basic research" as one of the missions to be pursued by the society. "This is an important rider," says Rudi Balling, scientific director of the German Research Centre for Biotechnology in Braunschweig, "but only time will tell if it keeps our Walter Kröll: the scientific freedom alive." centres will keep their autonomy.

Walter Kröll, director of the German Space Agency, who is likely to be named in November as the Helmholtz's next president, defends the reforms. Research planning according to public demands "is not incompatible with scientific freedom", he says. "The centres will be left with enough autonomy to develop their own scientific profiles."

The first Helmholtz Society centres were set up in the 1950s to research atomic energy. Over the years, their activities have diversified and they now employ 8,000 researchers between them, and cover areas such as molecular genetics, cancer research, plasma and particle physics, space technology, and environmental, marine and polar research.

\section{Summit to put education at the heart of Brazil's future}

\section{Ricardo Bonalume, São Paulo}

A fresh focus for Brazilian science is likely to emerge from a summit to be held on 18-21 September in Brasilia.

Organized by the Ministry of Science and Technology, the National Conference of Science, Technology and Innovation will attempt to determine Brazil's science and technology policy for the next 10 years.

According to a 250-page green paper written to help guide the meeting, policy should move on from the traditional focus of research investment to tackle two areas of perceived weakness: general levels of public education and industrial innovation.

"The great success of the 'Asian tigers' came largely from the role that families give to the education of their children," says physicist Cylon Gonçalves da Silva, former director of Brazil's national synchrotron at Campinas, near São Paulo. But the level of schooling for the average Brazilian has grown only slowly - from four years to six - since 1981, he points out.

Da Silva coordinated the 400 scientists involved in writing the green paper and helped to plan the conference's programme. The summit will involve representatives of scientific societies, industry and agriculture — the first such meeting since 1985. In the intervening years, Brazil has invested heavily in training $\mathrm{PhDs}$ and research, and has sharply increased its share of publications in leading international journals.

But a government freeze on university hiring means that the country is struggling to employ its new graduates. Writing in Nature $(413,16$; 2001), for example, four Brazilian researchers warn that "a whole generation of young PhDs will be lost to research".

"The idea of the conference is a very good one," says Glaci Zancan, a biochemist at the Federal University of Paraná and president of the Brazilian Society for the Advancement of Science. He says that it should focus on how science can help to address inequity in Brazilian society.

The meeting will help to produce a white paper on policy. But Brazil will elect a new president next year, and some fear that the new administration may ignore the paper, unless the meeting reaches a strong consensus on what it should say.

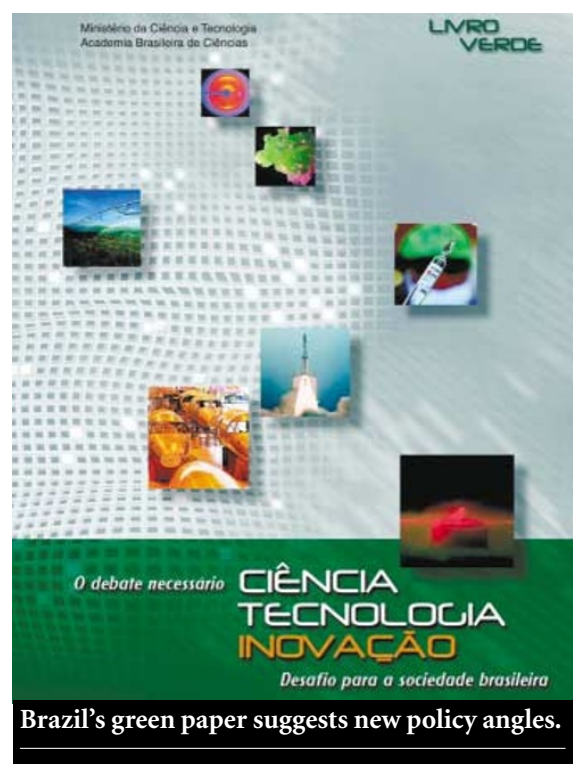

